\title{
Pseudoinversion of septal sutures in Middle Jurassic-Lower Cretaceous non-heteromorph ammonites
}

\author{
Mikhail A. Rogov' 1 (1)
}

Received: 30 December 2018 / Accepted: 19 March 2019/Published online: 2 April 2019

(C) Akademie der Naturwissenschaften Schweiz (SCNAT) 2019

\begin{abstract}
New records of ammonites showing poorly known sutural anomaly, so-called sutural pseudoinversion, are discussed. For the first time, sutural pseudoinversion was found in non-heteromorph Jurassic and Lower Cretaceous ammonoids, which are belonging to 10 genera (Dorsetensia, Indosphinctes, Erymnoceras, Pictonia, Aspidoceras, Kachpurites, Craspedites, Delphinites, Nikitinoceras and Immunitoceras) and 8 families (Sonniniidae, Pseudoperisphinctidae, Pachyceratidae, Aulacostephanidae, Aspidoceratidae, Craspeditidae, Neocomitidae and Parahoplitidae). Two types of sutural pseudoinversion were recognized: normal sutural pseudoinversion, in which the outline of small elements in lobes and saddles is fully reversed, and transitional sutural pseudoinversion, characterized by changes in the outline of folioles only. Usually, sutural pseudoinversion occurs in the terminal part of the phragmocone and becomes especially clear on the last sutures near the body chamber, but in some studied specimens sutural pseudoinversion appears in middle whorls and can be traced further up to the last visible sutures. Sutural pseudoinversion could not be caused by mechanical compression of saddles due to sutural asymmetry or strong development of sculptural elements as Bayer (Lethaia 11:307-313, 1978) assumed. Pseudoinversion is usually (although not always) visible in all sutural elements. Although pseudoinversion is known in those taxa with strong sutural asymmetry, pseudoinversion and asymmetry often affected different specimens. Influence of hydrostatic overpressure during the septal formation as well as parasite infestation on development of sutural pseudoinversion is considered to be unlikely. Instead, an abnormality appears to be a case of homeotic mutation, possibly caused by transcription errors in polarity genes. Much more common occurrence of sutural pseudoinversion in ammonites than it was expected previously suggest that it could be a relatively common phenomenon that needs increased attention in the future.
\end{abstract}

Keywords Ammonites · Septal suture $\cdot$ Sutural pseudoinversion · Jurassic $\cdot$ Cretaceous · Genetic anomaly

\section{Introduction}

As typical for cephalopods, ammonites are characterized by the presence of a chambered phragmocone. In contrast to their relatives, the aragonitic septa are extremely folded resulting in highly complex septal sutures in ammonites. During the last decades numerous hypotheses explaining key features of ammonite septal suture and septa formation were proposed (i.e., Westermann 1975; Seilacher 1975; García-Ruiz et al. 1990; García-Ruiz and Checa 1993;

Editorial Handling: D. Fuchs.

Mikhail A. Rogov

russianjurassic@gmail.com

1 Geological Institute of RAS, Pyzhevski lane 7, 119017 Moscow, Russia
Seilacher and Labarbera 1995; Hammer 1999; Barskov 1999; Klug et al. 2008; Inoue and Kondo 2016; see also Klug and Hoffmann, 2015 for review). Klug and Hoffmann (2015; pp. 76-79, Fig. 3.14) proposed an integrated chamber formation model, incorporating some previously suggested models. There is a general agreement among researchers that during the formation of a new chamber a balance of ambient pressure and the pressure within the new chamber occurred. However, few examples of socalled "pneumoseptal syndrome", e.g., when septa were damaged by overpressure due to siphuncular system disturbances are known (Keupp and Mitta 2004; Keupp 2012).

Ammonoid septal sutures are characterized by convex (saddles) and concave (lobes) elements of the first order. In the bulk of the Mesozoic ammonoids (with exception of some groups showing secondary simplification of septal suture during the ontogeny), saddles and lobes can further 
be subdivided into numerous secondary elements, named folioles (for minor convex elements) and lobules (for minor concave elements) (Klug and Hoffmann 2015, Fig. 3.1; see also Fig. 1). Ammonoid sutures are showing pointed lobules and rounded folioles (Ward and Westermann, 1976). As a very rare anomaly, only two specimens with partially inverted septal sutures were described for Late Cretaceous heteromorph ammonites (Westermann 1975; Ward and Westermann 1976; Henderson et al. 2002). Inversion has affected all folioles and lobules which are convex adapically instead of adorally, but not the principal saddle and

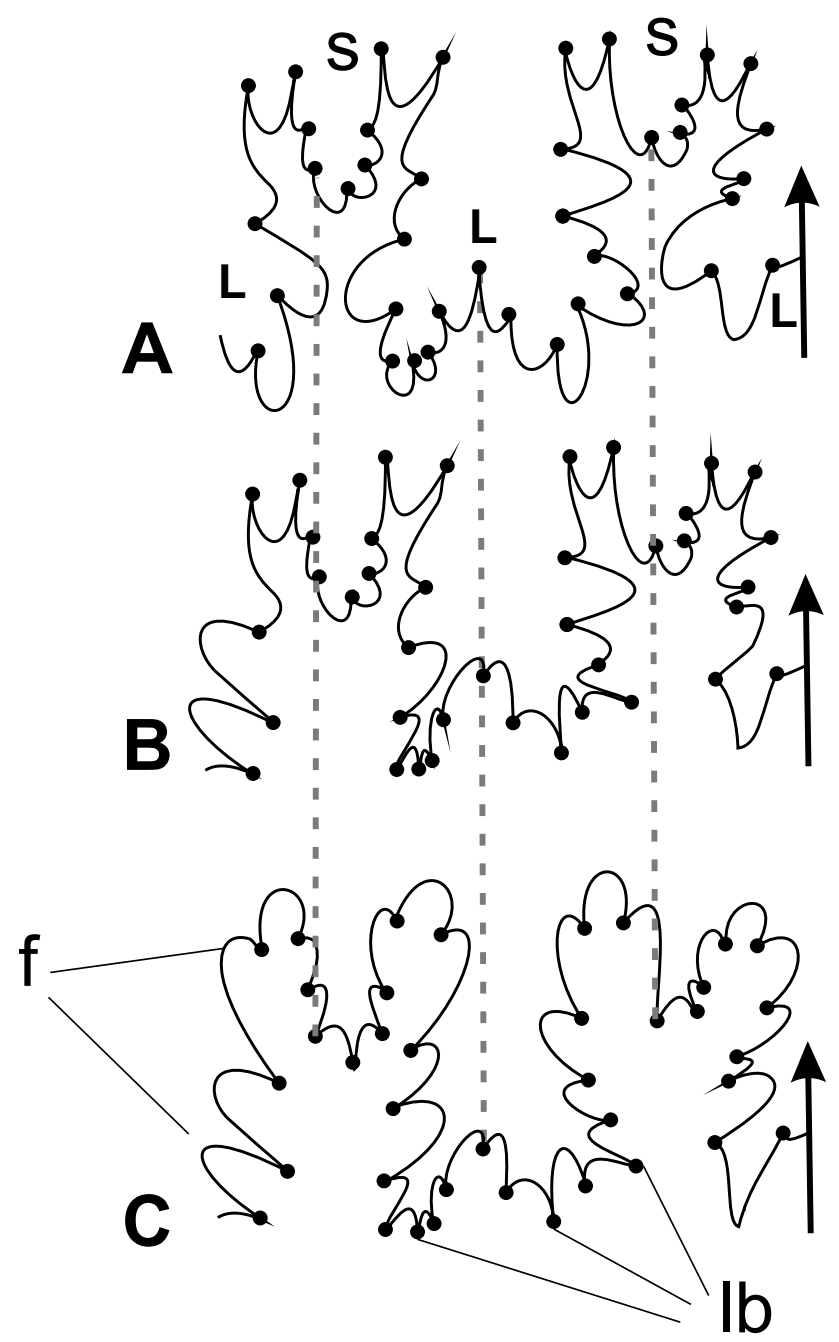

Fig. 1 Normal and pseudoinverted septal sutures $(\mathbf{a}, \mathbf{c}-$ after Ward and Westermann 1976). a-Part of suture No. 6 of Glyptoxoceras subcompressum (Forbes), representing pseudoinversion of normal type, with postulated tie-points (solid circles); $\mathbf{b}$ - Hypothetical septal suture with pseudoinversion of the transitional type, based on the same specimen; $\mathbf{c}-$ Normal septal suture, based on a reverted back to normal. Arrows indicate position of the siphuncle and direction towards aperture. $S$ saddles, $L$ lobes, $f$ folioles, $l b$ lobules; dotted lines are connecting the same tie-points in different examples of sutures lobes (Fig. 1). When this phenomenon was described for the first time (Westermann 1975; Ward and Westermann 1976) it was named "sutural inversion", but few years later Bayer (1978) argued that a full septal inversion (i.e. reverse of major sutural elements) is impossible and proposed to use the term "sutural pseudoinversion" for this phenomenon (see also Checa and García-Ruiz 1996). Aforementioned two examples are characterized by some differences in sutural pseudoinversion appearance. The specimen of Glyptoxoceras described by Ward and Westermann (1976) shows pseudoinversion only in the middle whorls, which is followed by normal sutures. In Baculites with only few last sutures preserved, all were pseudoinverted (Henderson et al. 2002). It should be noted that such "pseudoinverted" sutures were not known in preLate Cretaceous and/or non-heteromorph ammonites until now (with the exception of partially inverted sutures of Bifericeras figured and described by Bayer 1978). It should be noted that before the discovery of heteromorphs with sutural pseudoinversion Haas (1941) described a specimen of the Albian non-heteromorph ammonite Hysteroceras, which is characterized by full inversion of major sutural elements in the last suture lines. However, this record was questioned by Schindewolf (1968), who refuted Haas' observation argumenting that the relevant fragment was inversely inserted during specimen reassembly. A few years later, Westermann (1972) re-examined the specimen figured by Haas and supported Schindewolf's point of view, providing convincing evidence that this was a wrong insertion of the relevant ammonite fragment.

Here, I am presenting for the first time non-heteromorph ammonites which show prominent sutural pseudoinversion. The origin and significance of this anomaly will subsequently be discussed in a functional, phylogenetical and ecological context.

\section{Material}

During the last few years several new occurrences of septal pseudoinversion were discovered through careful study of ammonite sutures (Table 1, Fig. 2). The specimens included in this study (except for Craspedites (Taimyroceras) sachsi Igolnikov, Craspedites (C.) planus Shulgina, Pictonia (P.) flodigarriensis Matyja, Wierzbowski and Wright and Delphinites alatyrensis (Kemper)) are kept in the Paleontological Institute of Russian Academy of Science (PIN), Moscow, collection no. 5477. Other ammonites are available in Ivanov Geological Museum (Yaroslavl, IGM), CNIGR museum (Saint-Petersburg, CNIGR), Central Siberian Geological Museum (Novosibirsk, TsGSM), Vernadsky State Geological Museum (Moscow, GGM) and University of Warsaw (Warsaw, MWG UW). 


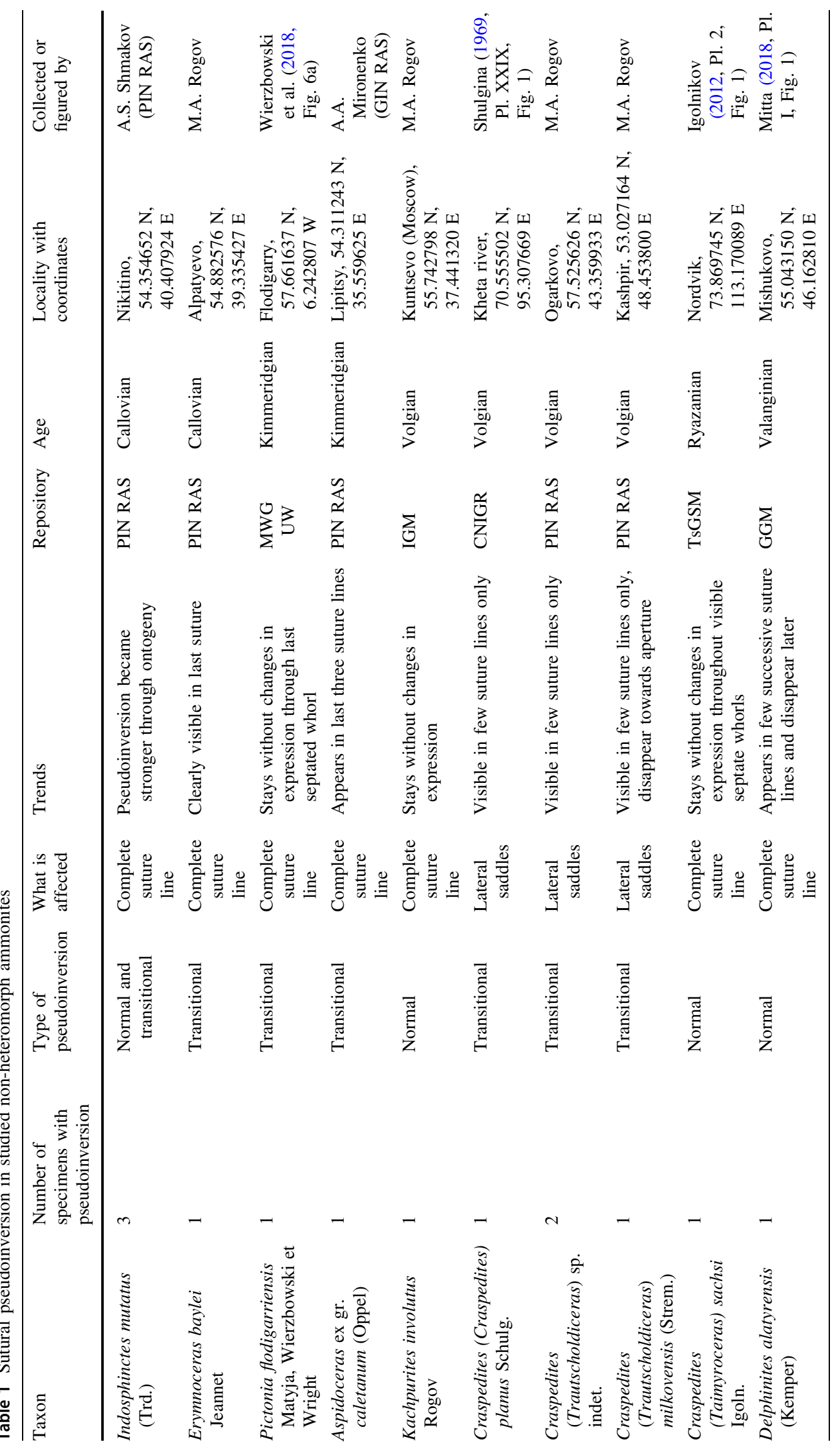




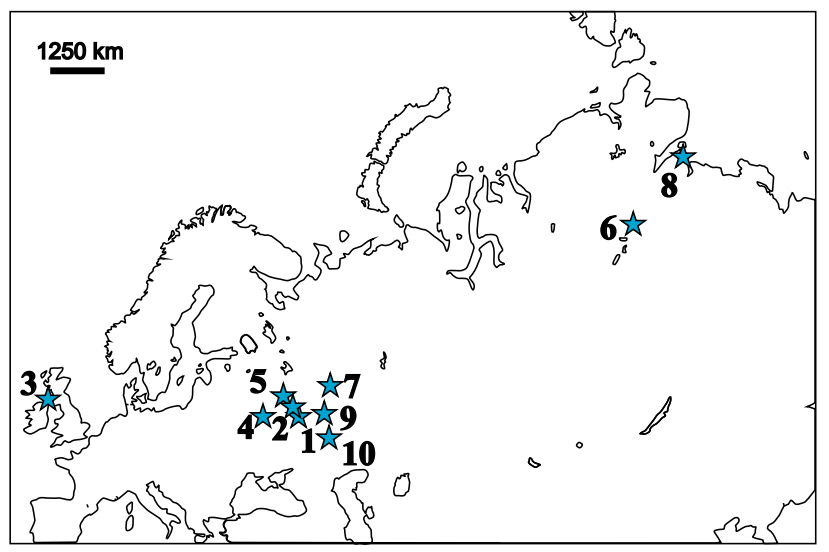

Fig. 2 Map showing localities of ammonites with sutural pseudoinversion, figured in this paper. 1-Nikitino; 2-Alpatyevo; 3Flodigarry; 4-Lipitsy; 5-Kuntsevo district, Moscow; 6-Kheta river, sections no. 18-19; 7-Ogarkovo; 8-Nordvik; 9-Mishukovo; 10-Kashpir

The ammonites studied are characterized by the presence of two distinct types of sutural pseudoinversion, ascribed to as normal and transitional types (Fig. 1). The normal type shows a reverse pattern of small elements of both lobes and saddles, i.e. folioles are pointed while saddle incisions are rounded; both examples of sutural pseudoinversion described previously in heteromorphs belong to this type. The transitional type, for the first time discovered in the studied specimens, is characterized by the presence of pointed folioles, while the outline of lobe incisions remains unchanged. Pseudoinversion commonly affects the complete suture line, although in some cases of the transitional type it could only be determined in some lateral saddles.

\section{Description}

The following records are described in stratigraphic order:

1. Indosphinctes mutatus (Trautschold) [Pseudoperisphinctidae, Lower-Middle Callovian boundary beds, Nikitino, Ryazan area, Figs. 2, 3, 4d, e]. This is a common macroconchiate species attaining up to $\sim 0.5 \mathrm{~m}$ diameter, widely distributed in the central part of the European Russia (Mitta 2000; Kiselev 2001). Among the 10 studied specimens three ammonites, all of which full-grown macroconchs, are characterized by a distinct sutural pseudoinversion. Two specimens show a prominent sutural pseudoinversion visible on the last whorl, especially in those sutures located near the body chamber. Inner whorls, well visible due to nearly evolute coiling of these shells are characterized by the transitional type, marked by pointed elements in the both saddles and lobes (Fig. 3). The transition from nearly normal to pseudoinverse sutures looks gradual. The second specimen (Fig. 4) shows the transitional sutural type throughout all whorls, whereas the third specimen is characterized by a shift from transitional to normal pseudoinversion; the latter is only visible at the last suture (Fig. 5d-e).

2. Erymnoceras baylei Jeannet [Pachyceratidae, Middle Jurassic, Middle Callovian, Coronatum Zone, Alpatyevo, Moscow area, Fig. 5a-c]. Pachyceratid ammonites from the Russian Platform are only known from the Middle Callovian Coronatum Zone (Kiselev 2001). Although relatively common, these ammonites are still insufficiently studied. Dimorphism of pachyceratids and species ranges within the Coronatum Zone are therefore still poorly known in this region (Kiselev and Rogov 2018). Sutural pseudoinversion of the transitional type, i.e. with pointed folioles and pointed lobules, is conceivable in the relatively small specimen represented by a piece of a whorl of a nearly full-grown microconch at the transition from phragmocone to body chamber. Sutural pseudoinversion appears exclusively on the last septal suture only, but clearly distinguished in all elements including those of the dorsal shell side (Fig. 5a-c).

3. Pictonia flodigarriensis Matyja, Wierzbowski and Wright [Aulacostephanidae, Upper Jurassic, Lower Kimmeridgian, Baylei Zone, Flodigarry, Fig. 6a, b]. This is the earliest species of the ammonite genus Pictonia. The first appearance of this species marks the lower boundary of the Kimmeridgian (Wierzbowski et al. 2016, 2018). Although being preserved as crushed flattened clayey phragmocone mold, the suture line is partially preserved. Sutural pseudoinversion of the transitional type is clearly visible in the last visible sutures.

4. Aspidoceras ex gr. caletanum (Oppel) [Aspidoceratidae, Upper Jurassic, Upper Kimmeridgian, Eudoxus Zone, Lipitsy, Kaluga area, Fig. 7a, b]. Aspidoceratids are abundant in the Upper Callovian-Lower Volgian of Central Russia. These ammonites are especially common in the Upper Kimmeridgian (Rogov and Shchepetova 2011). However, among the numerous specimens of this genus characterized by well-preserved suture lines only one full-grown macroconch exhibits transitional sutural pseudoinversion in the last quarter of its phragmocone. However, even visible septal sutures display a transition from non-inverted to transitional inverted pattern.

5. Kachpurites involutus Rogov [Craspeditidae, Upper Jurassic, lowermost Upper Volgian, Fulgens Zone, Kuntsevo district, Moscow, European part of Russia, Fig. 8a]. As other early members of the Garniericeratinae this is a common species and represents the 
Fig. 3 Indosphinctes mutatus (Trd.) with sutural pseudoinversion of the normal type. Specimen no. PIN 3582/5477, lateral view; Lower/ Middle Callovian transitional beds; Nikitino, Ryazan region, Russia; a-Full-grown specimen with body chamber; $\mathbf{b}$, c-suture lines of the inner whorl (b) and last sutures (c), enlarged

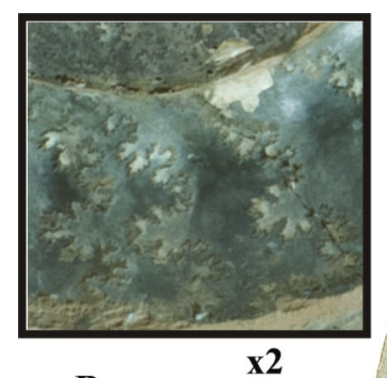

B

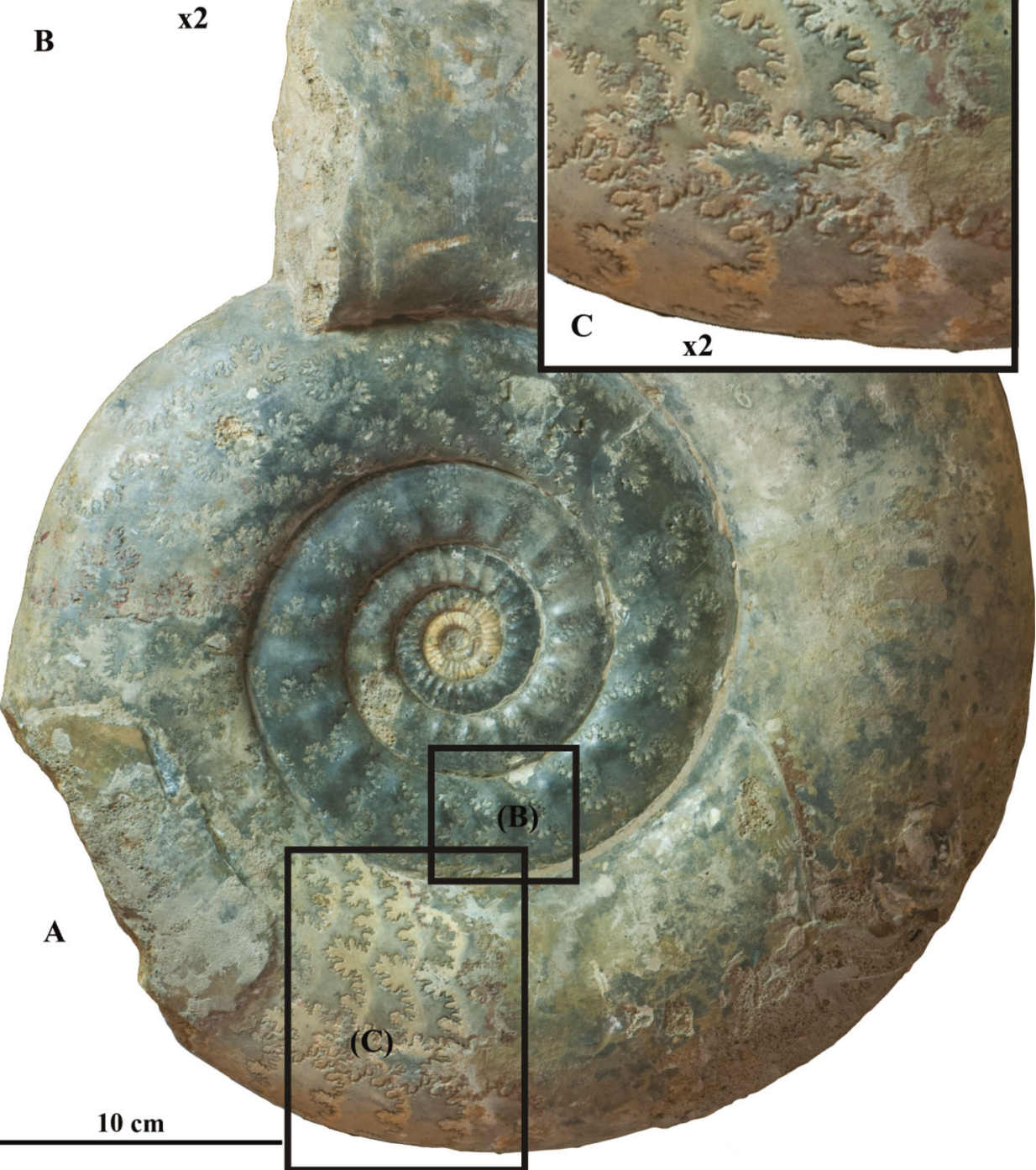

index of the involutus biohorizon (Rogov 2017). Despite a very small variability in shell outline and sculpture, this species is well characterized by variable septal sutures. Some specimens also show a clear sutural asymmetry. However, only one specimen with sutural pseudoinversion was found, but septal suture of this specimen is not asymmetrical. Unfortunately, due to partial preservation of the specimen, the ontogenetic appearance of the pseudoinversion remains unclear.

6. Craspedites (Craspedites) planus Shulgina. [Craspeditidae, Upper Jurassic, Upper Volgian, Okensis Zone,
Kheta river, northern Siberia, Fig. 8b]. This is the holotype of the $C$. $(C$.) planus species, described by Shulgina (1969) from the Khera river and published coated with ammonium chloride (Shulgina 1969, pl. XXIX, Figs. 1, 2) along with drawing of its suture (Shulgina 1969, Fig. 14.1). Although indistinct in the figure by Shulgina, a pseudoinversion of the transitional type can be determined. (Fig. 8b).

7. Craspedites (Trautscholdiceras) spp. [Craspeditidae, Upper Jurassic, Upper Volgian, Nodiger Zone, Ogarkovo and Kashpir, Figs. 8c, d, 9]. Specimens from the 
Fig. 4 Indosphinctes mutatus (Trd.) with sutural pseudoinversion of the transitional type. Specimen no. PIN 3664/5477, lateral view; Lower/Middle Callovian transitional beds; Nikitino, Ryazan region, Russia; a-bigsized septated specimen; $\mathbf{b}$ suture lines of the inner whorl, enlarged

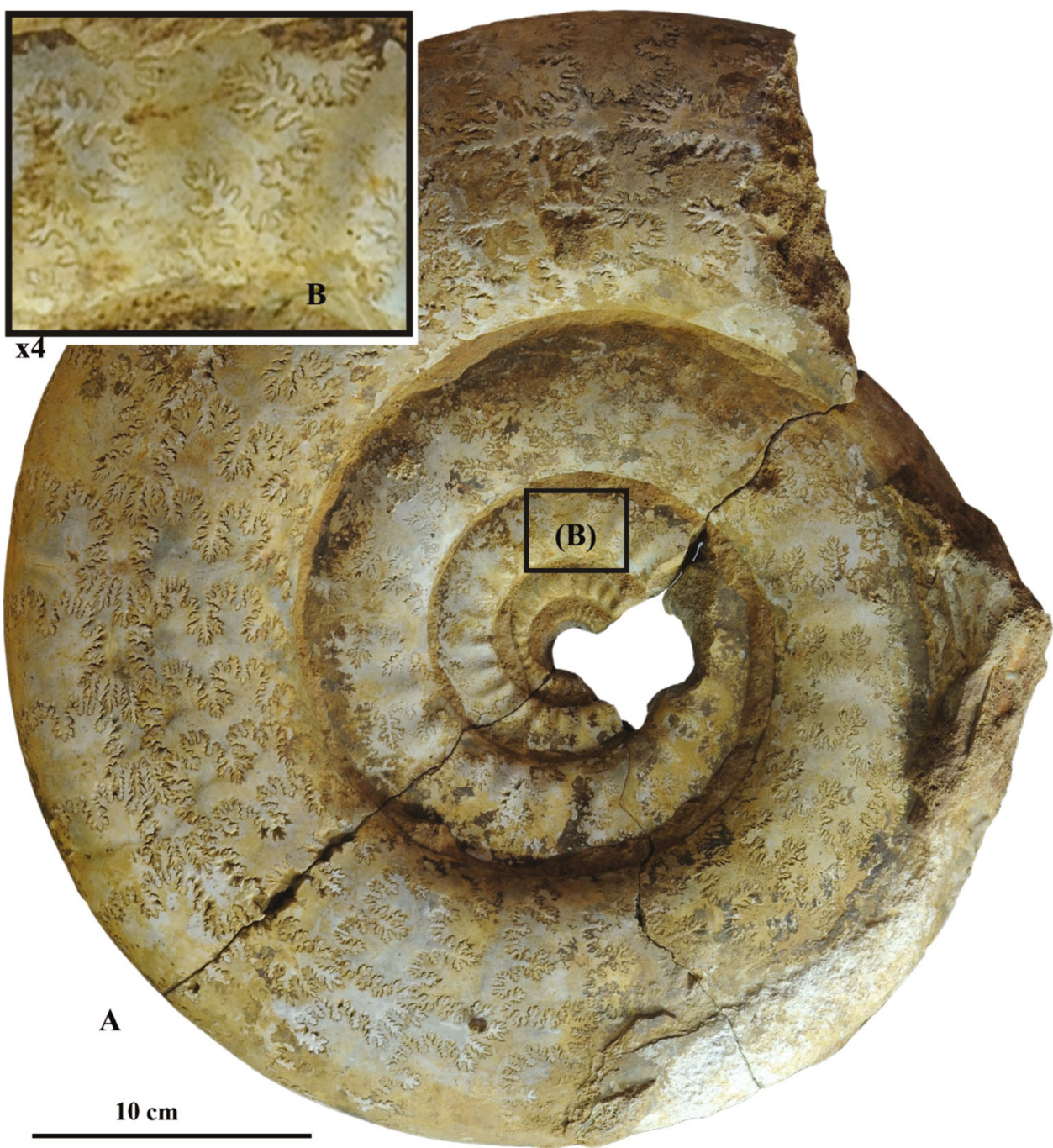

Ogarkovo section are characterized by a remarkable preservation. The phragmocone is filled with calcite; septal sutures and sutural membranes are clearly visible. Among the numerous specimens studied, two specimens $(C$. (T.) sp. juv.) exhibit the transitional type of sutural pseudoinversion in sutures near to the umbilical seam (Fig. 8c, d). However, septal sutures near the ventral side of these ammonites are not inverted. A similar pattern of sutural pseudoinversion can be observed in $C$. (T.) milkovensis (Stremoukhov) from the Middle Volga area. In addition, this specimen is also pseudoinverted along the flanks. This ammonite is further characterized by sutural asymmetry, which includes both asymmetrical position of ventral lobe and different structure of similar sutural elements on the opposite flanks (Fig. 9).

8. Craspedites (Taimyroceras) sachsi Igolnikov [Craspeditidae, Lower Cretaceous, lower Ryazanian,
Sibiricus Zone, Nordvik, Fig. 8e, f]. The detailed examination of the original photographs of the holotype of C. (Taimyroceras) sachsi Igoln. (Igolnikov 2012: Fig. 1a) revealed the presence of the normal type of pseudoinversion, which is visible through at least two whorls while in other shell parts sutures are obscured mainly by the nacreous layer.

9. Delphinites alatyrensis (Kemper) [Neocomitidae, Lower Cretaceous, lower Valanginian, Undulatoplicatilis Zone, Mishukovo, Chuvashia, Fig. 10]. This species has been figured recently by Mitta (2018: p 1. 1, Fig. 1a, b). Sutural anomalies in the Lower Valanginian genus Delphinites are wellknown. All specimens from the huge collection of Kemper belonging to Delphinites ( = Platylenticeras auct.) are characterized by a strong sutural asymmetry accompanied by siphonal asymmetry (Hengsbach 1977; Keupp 2012). By contrast, closely allied Tolypeceras (which is 
Fig. 5 a-c Erymnoceras baylei Jeannet with transitional sutural pseudoinversion; Middle Callovian, Coronatum Zone, Alpatyevo, Moscow area, specimen no. PIN 3681/5477; a-ventrolateral view; blateral view; c-dorsal view; d, e-Indosphinctes mutatus (Trd.) showing sutural pseudoinversion in the last septated whorl changing from transitional to normal type in last suture. Specimen no. PIN 3665/5477, lateral view; Lower/ Middle Callovian transitional beds; Nikitino, Ryazan region, Russia; d-full view; e-last suture lines, enlarged

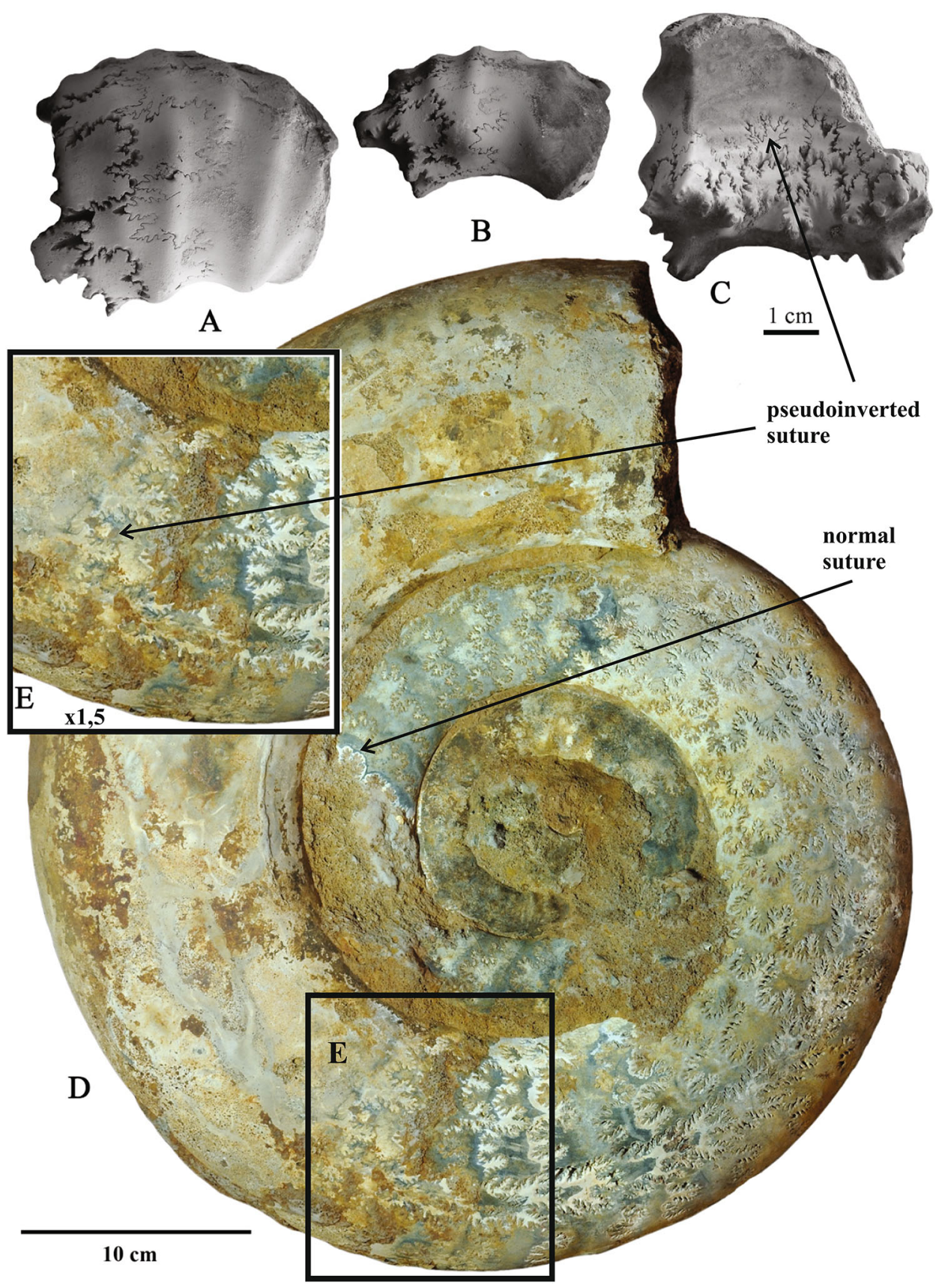

possibly synonymous with Delphinites)sometimes show non-asymmetric sutures. While studying Delphinites from the Volga area, Stchirowsky (1894) also indicated that some of the studied specimens are typified by symmetrical sutures. Nevertheless, until now sutural pseudoinversion was not reported in Delphinites. The specimen figured by Mitta (2018) and re-figured herein (Fig. 10) offers a pseudoinversion of the normal type which appears in the last quarter of the outer whorl (Fig. 10b). This anomaly is clearly seen in at least 5-6 successive sutures, but disappears in the last visible sutures. Pseudoinversion is especially distinct in the periumbilical part of the shell.

In addition to new occurrences described herein, two examples of sutural pseudoinversion in Aptian-Albian ammonites were recently figured by Robert et al. (2018: Fig. 12d, f). However, at least in one example (Robert et al. 2018: Fig. 12d) sutural pseudoinversion is missing, 
Fig. 6 Pictonia (Pictonia) flodigarriensis Matyja, Wierzbowski and Wright with transitional sutural pseudoinversion, lateral view; Lower Kimmeridian, Baylei Zone, flodigarriensis horizon, Flodigarry, Isle of Skye; specimen no. MWG UW ZI/94/ 01-55/ST 837 (Wierzbowski et al. 2018, Fig. 6a), a-full view; $\mathbf{b}$ - enlarged photo of septal suture showing pseudoinversion

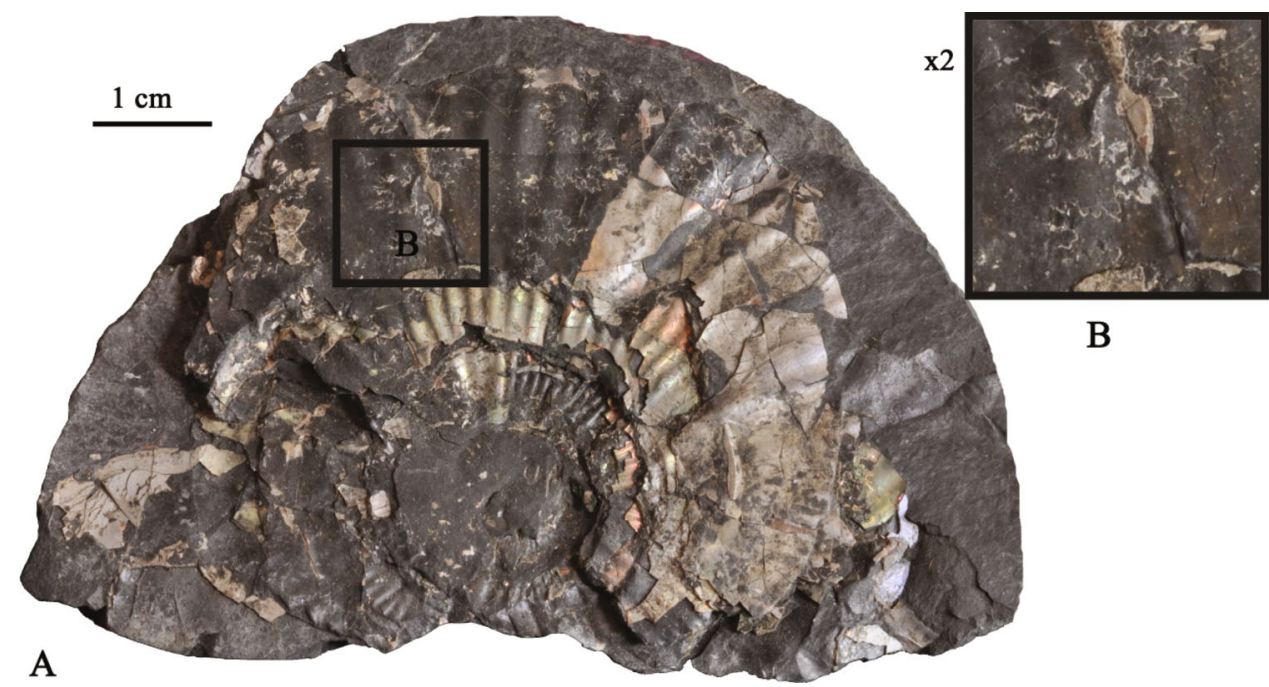

because the suture is figured in inverted pattern. This became clear after examination of the photograph of studied specimen, courtesy provided by J. A. Moreno. The second specimen, belonging to the genus Immunitoceras (Late Aptian of Northern Mexico) shows the transitional type of the sutural pseudoinversion.

More ammonite taxa with transitional pseudoinversion were found through careful study of specimens figured in older publications. For instance in few specimens of the early Bajocian sonniniid ammonites Dorsetensia liostraca Buckman, figured by Huf (1968: Taf. 40, Fig. 1; Taf. 46, Fig. 2), transitional type of the pseudoinversion is occurred. The ontogenetic appearance of such anomalies, however, remains unclear. Transitional pseudoinversion was also wound in Valanginian craspeditid Nikitinoceras (Costamenjaites) troelseni (Jeletzky) (Jeletzky 1979: pl. p, Fig. 1f).

\section{Discussion and conclusions}

The new findings suggest that septal pseudoinversion is a much more common phenomenon than thought before. In non-heteromorph ammonites, two different types of sutural pseudoinversion could be recognizednormal and transitional sutural pseudoinversion. Both types of pseudoinversion occurred within different ammonoid lineages (Fig. 11). Appearance of such an anomaly cannot be explained by mechanical reasons (as suggested by Bayer 1978), because with few exceptions (Craspedites (Trautscholdiceras) milkovensis and Delphinites alatyrensis described herein) the studied examples of sutural pseudoinversion are not related to either sutural or sculptural asymmetries. Nevertheless, even in those specimens with both sutural asymmetry and pseudoinversion (Figs. 9, 10), pseudoinversion is visible on both flanks and thus cannot be caused by mechanical deformation of sutures. There are no traces of injures in all studied specimens showing septal pseudoinversion. Parasite infestation is considered as a possible reason for at least some examples of sutural asymmetry in ammonites (cf. Hengsbach 1986; Keupp 2012). However, it appears unlikely for sutural pseudoinverion, which is usually affected by all sutural elements or at least by some elements symmetrically located in relation to the ventral side of the shell. During the formation of ammonite septa nearly equal hydrostatic pressure existed in body chamber and newly forming septa. Thus dysfunction of the siphuncle could lead to a pressure imbalance between the body chamber and the last chamber of phragmocone and to errors in septa formation. Sutural pseudoinversion could be caused by such an increased chamber pressure during the septal formation, but in contrast with other known examples of septa damaged by overpressure ("pneumoseptum" described by Keupp and Mitta 2004; Keupp 2012), the general outline of septa remains unchanged and pseudoinversion affected only minor sutural elements. Henderson et al. (2002) have interpreted sutural pseudoinversion with a genetic abnormality leading to homeotic transformation in which the plan for a certain body region becomes translocated to another. It should be noted, however, that in those specimens with sutural pseudoinversion appears late in the ontogeny, it could only be recognized in some saddles, while other saddles within the same suture looks normal. Influence of genetic anomalies [such as erroneous expression of engrailed (Baratte et al. 2007) or other so-called 'segment polarity genes' (Vellutini and Hejnol 2016)] is possible, although pseudoinversion could also be 
Fig. 7 Aspidoceras cf. caletanum (Oppel) with transitional sutural pseudoinversion, lateral view; Upper Kimmeridian, Eudoxus Zone, Lipitsy, Kaluga region; specimen no. PIN 3685/5477, a-full view; b-enlarged photo of last sutures showing pseudinversion

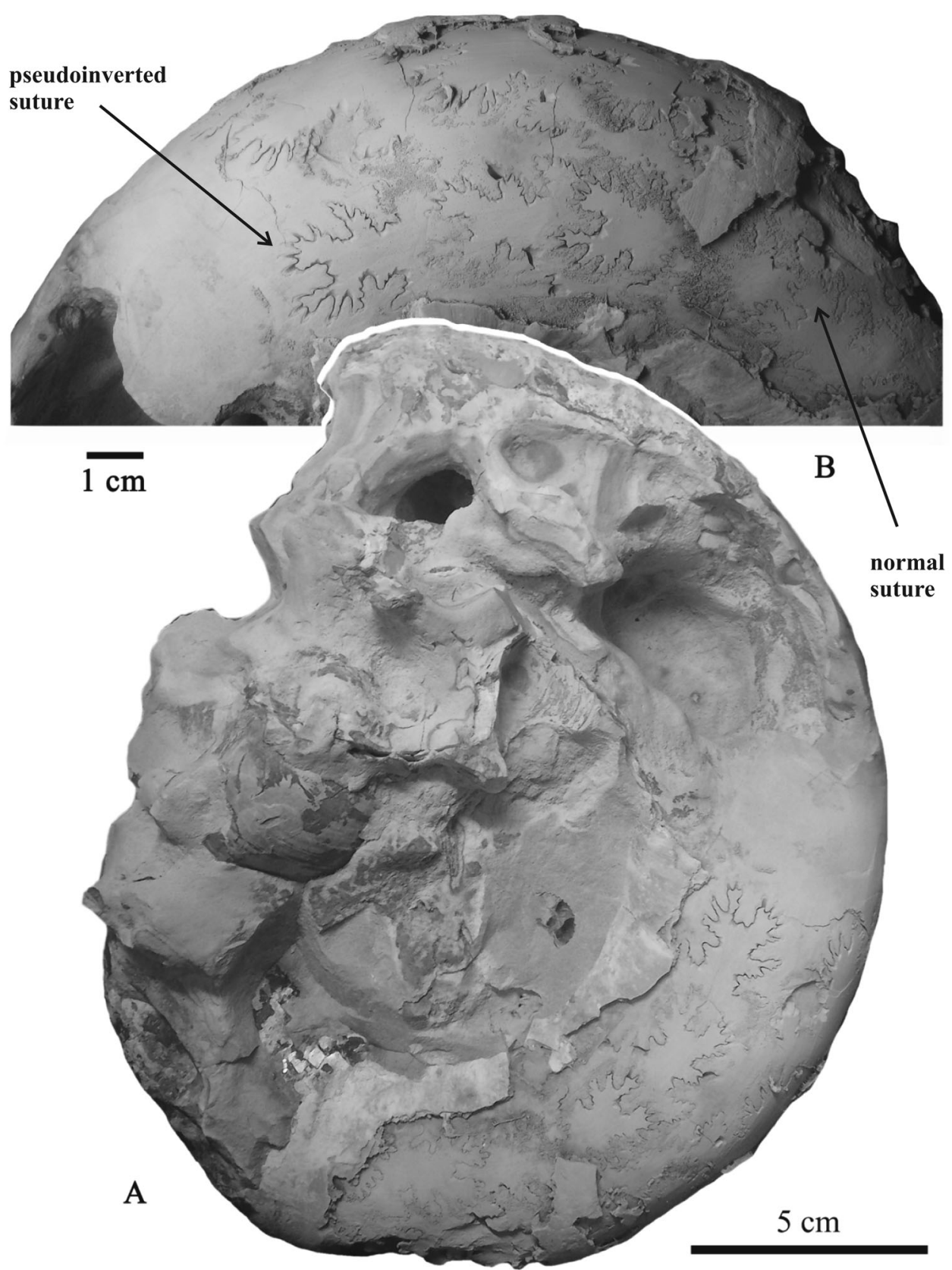

influenced by epigenetic mechanisms directly affecting late stages of ammonite development. The appearance of sutural pseudoinversion is not related to a wide range of variability. However, it is important to note that nearly half of studied taxa are characterized by relatively common occurrence of sutural asymmetry. For example, strong sutural asymmetry was observed recently in some specimens of Indosphinctes (pers. comm. by Mironenko, January 2019), Aspidoceras (Vigh 1981; Hengsbach 1986) and it is especially typical in Delphinites (Kemper 1961; Hengsbach 1977, 1986). Some Upper Volgian craspeditid taxa with sutural pseudoinversion also show numerous examples of specimens with asymmetrical sutures. For example, up to $20 \%$ of the Kachpurites involutus population are characterized by sutural asymmetry, while Craspedites (Trautscholdiceras) include $40-80 \%$ of asymmetrical specimens in different palaeopopulations (Mironenko and Rogov 2019), and sutural asymmetry is considered as a typical feature of Craspedites (Trautscholdiceras) (Sazonova and Sazonov 1984). Although sutural asymmetry and sutural pseudoinversion affected different specimens, the general aptitude to develop sutural 

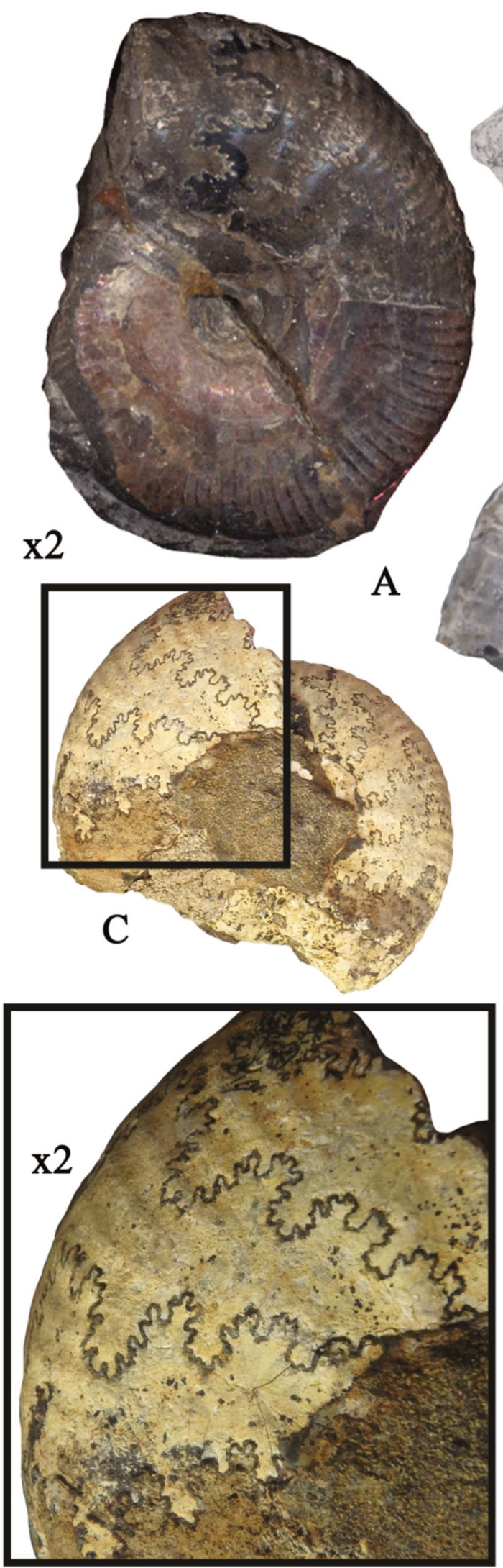

$1 \mathrm{~cm}$

D
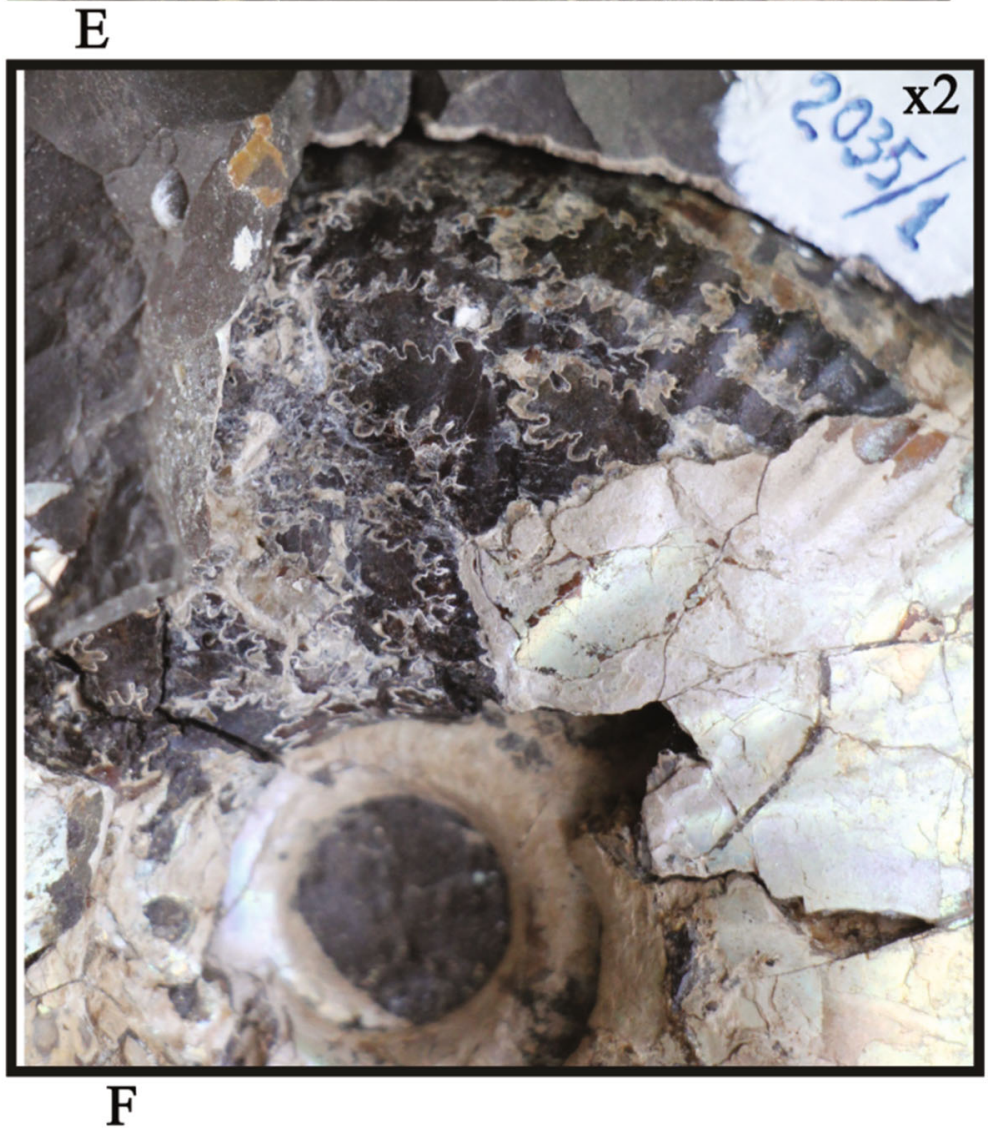
4Fig. 8 a-Kachpurites involutus Rogov with normal sutural pseudoinversion, lateral view; Upper Volgian, Fulgens Zone, involutus horizon, Kuntsevo district, Moscow; specimen no. IGM MK 4148/2; b-Craspedites (Craspedites) planus Schulg., with transitional sutural pseudoinversion, lateral view; Upper Volgian, Okensis Zone, Kheta river, northern Siberia, specimen no CNIGR 51/9565; c, dCraspedites (Trautscholdiceras) sp. juv. with weakly developed transitional pseudinversion, Upper Volgian, Nodiger Zone, Ogarkovo, Kostroma region, specimen no. PIN 3682/5477; e, f-Craspedites (Taimyroceras) sachsi Igoln. with normal pseudoinversion, lateral view; lower Ryazanian, Sibiricus Zone, Nordvik, northern Siberia; specimen no. TsSGM 2035/1; e-full view; b-enlarged photo of inner whorls showing early appearance of pseudoinversion

anomalies in aforementioned taxa should be considered as an additional evidence for genetic causes. In those taxa with rare sutural asymmetries, its causes could be different (including parasitism, construction morphology or environmental influence-see Hengsbach 1986 for review). Examples of sutural pseudoinversion described in this paper as well as reported previously in heteromorphs are characterized by very variable patterns of appearance, disappearance and degree of expression of this anomaly. Most enigmatic is the disappearance of pseudoinversion during the ammonoid ontogeny, which is clearly seen in Glyptoxoceras described by Ward and Westermann (1976) and in specimens of Delphinites (this paper). The disappearance during the ontogenetic development of some specimens could be explained by epigenetic mechanisms (for example through DNA methylation or through other non-genetic processes influencing individual development, see for details Cabej 2012). The presence of sutural pseudoinversion in a number of studied specimens (such as Indosphinctes and Craspedites (Trautscholdiceras)) suggest that this anomaly did not significantly affected development and life of ammonites. Ammonites with sutural pseudoinversion are represented by adult specimens (except fragmentary specimens whose final size remains unknown) thus such an anomaly did not affect growth. The same seems to be true for sutural anomalies (sutural asymmetry), which sometimes are typical for long-ranging ammonoid species. However, ammonites with abundant sutural asymmetry belong to relatively high-latitude assemblages and show very low taxonomic diversity.

A significant number of new records of non-heteromorph ammonites with sutural pseudoinversion made during the last years suggest that this phenomenon could be relatively common. Careful study of ammonite sutures will possibly provide new evidence for additional occurrence of septal pseudoinversion among Mesozoic ammonoids.
Fig. 9 Craspedites

(Trautscholdiceras) milkovensis (Strem.), showing both sutural asymmetry and weak transitional pseudinversion, Upper Volgian, Nodiger Zone, Kashpir, Samara region, specimen no. PIN 3684/5477, a, c-lateral views, b-ventral view; scale bar $=1 \mathrm{~cm}$

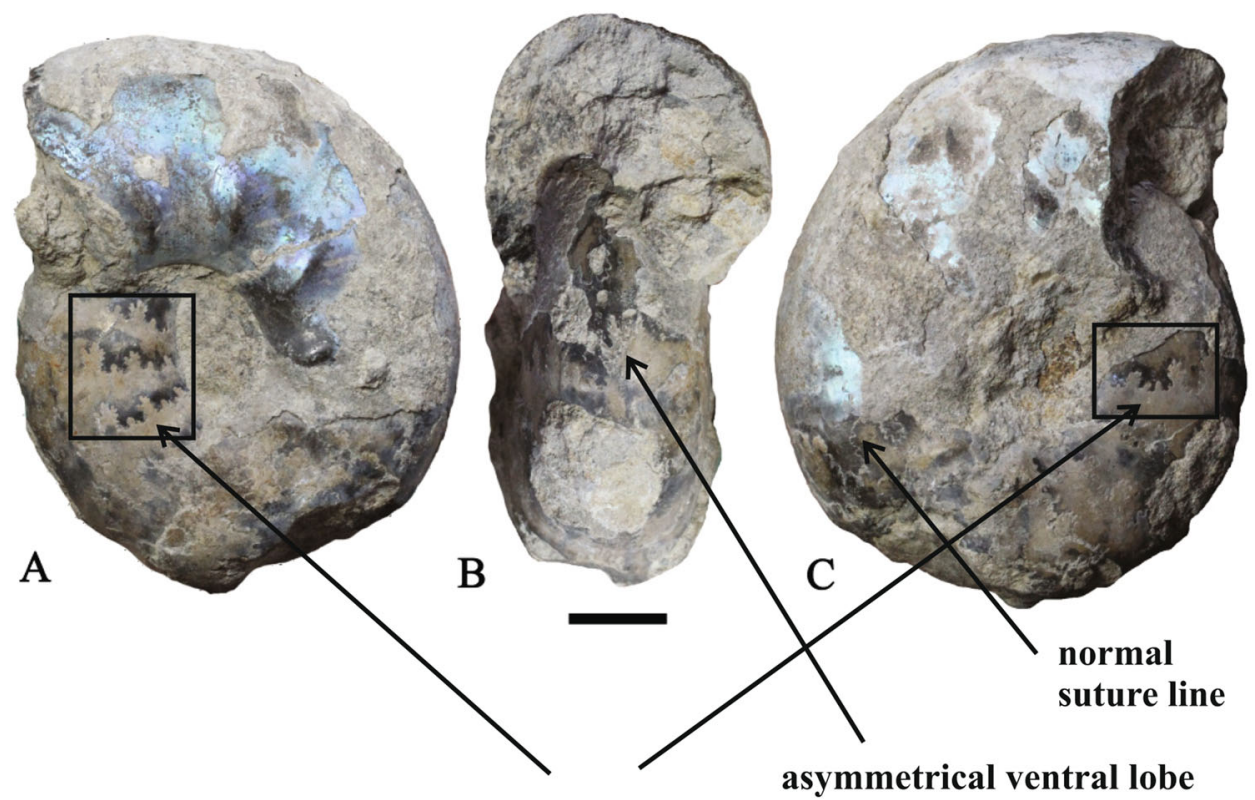

pseudoinverted lateral saddles 
Fig. 10 Delphinites alatyrensis (Kemper), with normal sutural pseudoinversion affected some suture lines but disappearing later. Lower Valanginian, Undulatoplicatilis Zone,

Mishukovo, Chuvashia, specimen no. GGM II-117/841. $\mathbf{a}-$ Natural size, $\mathbf{b}$ - enlarged $($ scale bar $=1 \mathrm{~cm})$
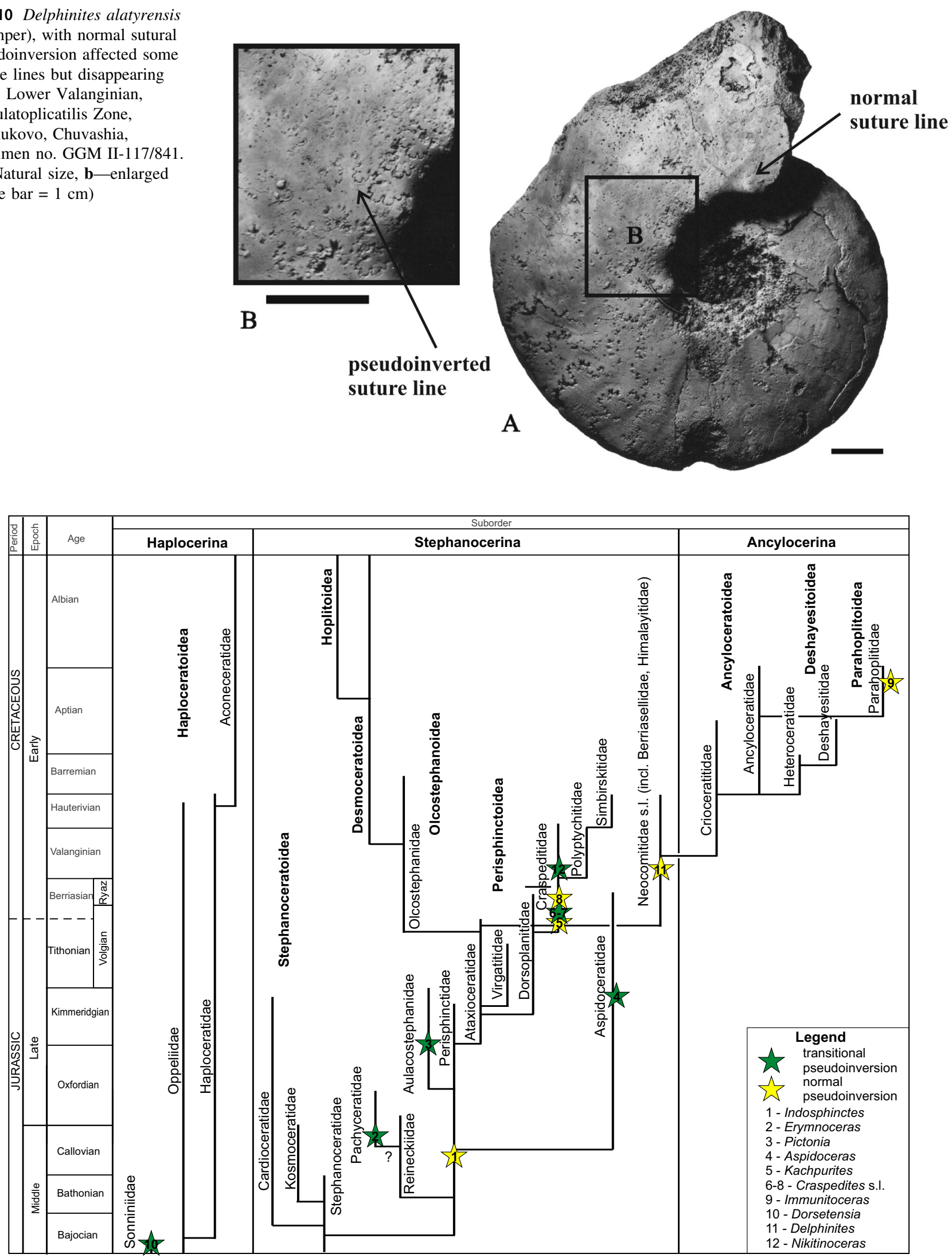

Fig. 11 Family-level phylogeny of Middle Jurassic-Lower Cretaceous ammonites [after Besnosov and Michailova (1991), Page (2008) and Shevyrev (2006)] and distribution of sutural pseudoinversion 
Acknowledgements This study was supported by RFBR Grant No. 18-05-01070 and followed the research plan of the Geological Institute of RAS No. 0135-2018-0035. I am indebted to Aleksei Shmakov (Paleontological Institute of RAS, Moscow), Aleksandr Mironenko (Geological Institute of RAS, Moscow), Aleksandr Igolnikov (Institute of Petroleum Geology and Geophysics, Novosibirsk), Vasily Mitta (Paleontological Institute of RAS, Moscow), Josep A. MorenoBedmar (Universidad Nacional Autónoma de México, Mexico) and Andrzej Wierzbowski (Warsaw University, Warsaw, Poland) for providing some of the studied specimens or their photographs. The comments by two anonymous reviewers significantly improved this manuscript.

\section{References}

Baratte, S., Andouche, A., \& Bonnaud, L. (2003). Involvement of DivIVA in the morphology of the rod-shaped actinomycete Brevibacterium lactofermentum. Microbiology, 149,3531.

Barskov, I. S. (1999). Why ammonoids have complex septa and sutures? In Fossil Cephalopods: Recent advances in their study (pp. 53-61). Moscow: PIN RAS.

Bayer, U. (1978). The impossibility of inverted suture lines in ammonites. Lethaia, 11, 307-313.

Besnosov, N. V., \& Michailova, I. A. (1991). Higher taxa of Jurassic and Cretaceous Ammonitida. Paleontological Journal,25(4), $1-19$.

Cabej, N.R. (2012). Epigenetic Principles of Evolution. Elsevier, 818 p.

Checa, A. G., \& García-Ruiz, J. M. (1996). Morphogenesis of the septum in ammonoids. Ammonoid paleobiology (pp. 253-296). Boston, MA: Springer.

García-Ruiz, J. M., Checa, A., \& Rivas, P. (1990). On the origin of ammonite sutures. Paleobiology, 16, 349-354.

García-Ruiz, J. M., \& Checa, A. (1993). A model for the morphogenesis of ammonoid septal sutures. Geobios,26, 157-162.

Haas, O. O. (1941). A case of inversion of suture lines in Hysteroceras varicosum (Sow.). American Journal of Science, 239, 661-664.

Hammer, Ø. (1999). The development of ammonoid septa: an epithelial invagination process controlled by morphogens? Historical Biology, 13(2-3), 153-171.

Henderson, R. A., Kennedy, W. J., \& Cobban, W. A. (2002). Perspectives of ammonite paleobiology from shell abnormalities in the genus Baculites. Lethaia,35, 215-230.

Hengsbach, R. (1977). Zur Sutur-Asymmetrie bei Platylenticeras (Ammon., Kreide). Zoologische Beitraege, Neue Folge,23, 459-468.

Hengsbach, R. (1986). Zur Kenntnis der Sutur-Asymmetrie bei Ammoniten. Senckenbergiana lethaea,67, 119-149.

Huf, W. (1968). Über Sonninien und Dorsetensien aus dem Bajocium von Nordwestdeutschland. Beihefte zum Geologischen Jahrbuch, 64, 1-126.

Igolnikov, A. E. (2012). Craspedites (Vitaliites?) sachsi, a new Boreal Berriasian ammonite species of the North of Eastern Siberia (Nordvik Peninsula). Paleontological Journal,46(1), 12-15.

Inoue, S., \& Kondo, S. (2016). Suture pattern formation in ammonites and the unknown rear mantle structure. Scientific Reports, 6, 33689; doi: 10.1038/srep33689

Jeletzky, J. A. (1979). Eurasian craspeditid genera Temnoptychites and Tollia in the Lower Valanginian of Sverdrup Basin, district of Franklin, with comments on taxonomy and nomenclature of Craspeditidae. Geological Survey of Canada Bulletin,299, 1-89.

Kemper, E. (1961). Die Ammonitengattung Platylenticeras (=Garnieria). Beihefte zum Geologischen Jahrbuch,47, 1-195.
Keupp, H. (2012). Atlas zur Paläopathologie der Cephalopoden. Berliner Paläobiologische Abhandlungen,12, 1-390.

Keupp, H. \& Mitta, V.V. (2004). Septenbildung bei Quenstedtoceras (Ammonoidea) von Saratov (Russland) unter anomalen Kammerdruckbedingungen. Mitteilungen aus dem GeologischPaläontologischen Institut der Universität Hamburg, 88, 51-62.

Kiselev, D. N. (2001). Zones, Subzones and biohorizons of the Central Russia Middle Callovian. Publications of the Pedagogical University of Yaroslavl, Natural-Geographical Faculty Special Paper, 1, 1-38. [in Russian].

Kiselev, D. N., \& Rogov, M. A. (2018). Detailed biostratigraphy of the Middle Callovian - lowest Oxfordian in the Mikhaylov reference section (Ryazan region, European part of Russia) by ammonites (pp. 73-186). XVI: Volumina Jurassica.

Klug, C., Meyer, E. P., Richter, U., \& Korn, D. (2008). Soft-tissue imprints in fossil and recent cephalopod septa and septum formation. Lethaia,41, 477-492.

Klug, C., \& Hoffmann, R. (2015). Ammonoid septa and sutures. In Ammonoid Paleobiology: From anatomy to ecology (pp. 45-90). Springer, Dordrecht.

Mironenko, A.A., \& Rogov, M.A. (2019). Asymmetry of septal suture in Late Jurassic ammonites (Craspeditidae) from Central Russia localities. In Alekseev A.S. (Ed.) Paleostrat-2019. Annual meeting of paleontological section of Moscow Society of Naturalists and Moscow Branch of the Palaeontological Society (pp. 46-47). Moscow: PIN RAS. [in Russian]

Mitta, V. V. (2000). Ammonites and biostratigraphy of the Lower Callovian of Russian Platform. Bulletin of CF VNIGNI,3, 1-144. [in Russian].

Mitta, V. V. (2018). The Genus Delphinites Sayn (Ammonoidea: Neocomitidae) in the Lower Valanginian of the Russian Platform. Paleontological Journal,52, 1504-1516.

Page, K. N. (2008). The evolution and geography of Jurassic ammonoids. Proceedings of the Geologists' Association,119, $35-57$.

Robert, E., Samaniego-Pesqueira, A., Moreno-Bedmar, J. A., \& González-León, C. M. (2018). Aptian and Albian (Early Cretaceous) ammonites from Lampazos and the Bisbee groups (Sonora State, northwest Mexico). Cretaceous Research,86, $1-23$.

Rogov, M. A. (2017). Ammonites and infrazonal stratigraphy of the Kimmeridgian and Volgian Stages of southern part of the Moscow Syneclise. Transactions of the Geological Institute, 615, 7-160. [in Russian].

Rogov, M.A. \& Shchepetova, E.V. (2011). New data on sedimentology and biostratigraphy of the Upepr Kimmeridgian Eudoxus Zone near the border of Ulianovsk region and Tatarstan. In: Jurassic System of Russia: Problems of stratigraphy and paleogeography. Fourth All-Russian meeting. September 26-30, 2011, St.-Petersburg. Scientific materials. (pp.186-189). Lema, St.-Petersburg. [in Russian]

Sazonova, I. G., \& Sazonov, N. T. (1984). Berriassian of the Boreal provinces of Europe. Bulletin of Moscow Society of Naturalists, series geology,59(1), 86-97. [in Russian].

Schindewolf, O. H. (1968). Homologie und Taxonomie. Acta Biotheoretica, 18, 235-283.

Seilacher, A. (1975). Mechanische Simulation und funktioneile Evolution des Ammoniten Septums. Paläontologische Zeitschrift,49(3), 268-286.

Seilacher, A., \& Labarbera, M. (1995). Ammonites as Cartesian divers. Palaios, 10, 493-506.

Shevyrev, A. A. (2006). The Cephalopod macrosystem: A historical review, the present state of knowledge, and unsolved problems: 3. Classification of Bactritoidea and Ammonoidea. Paleontological Journal,40, 150-161. 
Shulgina, N. I. (1969). Volgian ammonites. In V. N. Sachs (Ed.), Fundamental section of the Upper Jurassic deposits of Kheta river basin (pp. 125-162). Leningrad: Nauka. [in Russian].

Stchirowsky, W. (1894). Ueber ammoniten der Genera Oxynoticeras und Hoplites aus dem nord-simbirsk'schen Neocom. Bulletin de la Société impériale des naturalistes de Moscou, Nouvelle série, VII (pp. 369-380).

Vellutini, B. C., \& Hejnol, A. (2016). Expression of segment polarity genes in brachiopods supports a non-segmental ancestral role of engrailed for bilaterians. Scientific reports, 6, 32387.

Vigh, G. (1981). Neue sowie pathologische Brachiopoden und Ammoniten aus den jurassischen Schichten des KalvarienHügels von Tata. A Magyar Állami Földtani Intézet évi jelentése, 1979, 333-355.

Ward, P. D., \& Westermann, G. E. G. (1976). Sutural inversion in a heteromorph ammonite and its implication for septal formation. Lethaia,9, 357-361.
Westermann, G. E. G. (1972). The case of alleged inversion of septal sutures in ammonites. Lethaia,5, 165-167.

Westermann, G. E. G. (1975). Model for origin, function and fabrication of fluted cephalopod septa. Paläontologische Zeitschrift,49, 235-253.

Wierzbowski, A., Atrops, F., Grabowski, J., Hounslow, M., Matyja, B. A., Olóriz, F., et al. (2016). Towards a consistent OxfordianKimmeridgian global boundary: Current state of knowledge. Volumina Jurassica, 16, 15-50.

Wierzbowski, A., Matyja, B. A., \& Wright, J. (2018). Notes on the evolution of the ammonite families Aulacostephanidae and Cardioceratidae and the stratigraphy of the uppermost Oxfordian and lowermost Kimmeridgian in the Staffin Bay sections (Isle of Skye, Northern Scotland). Volumina Jurassica, 16, 27-50. 